Staffordshire; (2) the incoming of marine conditions in the Millstone Grits as they are traced northwards; (3) the possible correlation of the Alton (Ganister) Coal and its marine roof with the Slatyband Ironstone of Scotland, a correlation adopted by Hull ; (4) the probable Lanarkian age of the measures below the Kilburn Coal of North Derbyshire; (5) the many marine bands containing Productids in the Westphalian (Middle) Coal Measures of the Midland Province; (6) a considerable thickness of barren measures not infrequently of a red colour, high up in the Westphalian Coal Measures, but below the Staffordian Coal Measures, and their possible correlation with the barren red measures of Fife and Midlothian; (7) the not infrequent occurrence of a marine bed resting directly on a seam of coal and the persistence of such seams of coal even when a few inches in thickness.

\title{
CORRESPONDENCE.
}

\section{THE MAGNESIAN GROUP OF IGNEOUS ROCKS.}

SIR,-The interesting paper appearing in your November number under the title: "The Magnesian Group of Igneous Rocks," raises a number of points which seem to require some further discussion. It is to a few of these only that I wish to refer here. The application of the term " magnesian" to a group of igneous rocks, the ultrabasic members of which alone show notable content of $\mathrm{MgO}$, is an innovation that appears scarcely justified. In the intermediate and acid types it is iron and not magnesium which calls for note. The peculiar properties of this group of rocks are of a provincial order in a petrographic sense, and serve to rank the group as a distinct unit of the calc-alkaline suite, rather than a group co-ordinate with this suite. Amongst the "magnesian" provinces listed by Mr. Dixey there are some whose inclusion requires some further word of explanation. Number 7, in particular, finds itself among strange companions. Some of the characteristics of these rocks are explicable on the assumption of a low active mass of water in the magma, combined in certain cases with high pressure during consolidation.

A low magmatic water content may lead to an early precipitation of potash felspar, and we may note that orthoclase or microperthite is a not uncommon feature in the basic types, as in the Norwegian norites and the basic members of the Eyre Peninsula group. It is to this early precipitation of potash felspar that the occurrence of oligoclase or andesine as the plagioclase constituent of the microperthite in the basic types is due. This feature is best exemplified in the rocks of Western Norway. The occurrence of hypersthene in the intermediate and acid types is probably explicable on these lines. In the absence of abundant water the degradation of the metasilicate molecule to the orthosilicate type is inhibited, so 
that hypersthene appears instead of biotite, as in the equation

$$
\text { biotite }+ \text { quartz } \longrightarrow \text { hypersthene + orthoclase. }
$$

The presence of garnet (almandine) in the more acid types at least, is also an expression of a low active mass of water to wbich may be added the influence of high pressure (Q.J.G.S., 1921, p. 94). While the occurrence of hypersthene in acid charnockitic rocks may thus be ascribed to a comparative poorness in magmatic water, it is of interest to note that hypersthene is also found in acid rocks which otherwise cannot be included in this group. In such abnormal cases its presence can be ascribed to hybridism. This is the case with certain acid gneisses in the island of Rum, described by Dr. Harker. The conversion of olivine to enstatite (hypersthene) supplies an explanation in some cases where olivine is a constituent of the absorbed material. The monoclinic pyroxene of acid igneous rocks is characteristically a non-aluminous type, and it is not improbable that an aluminous type is unstable in the presence of quartz. Where acid rocks have been contaminated with basic material such as gabbro, the aluminous pyroxene of the latter might be expected to react with silica as in the equation :-

$$
\left\{\begin{array}{l}
\mathrm{xCaMgSi}_{2} \mathrm{O}_{6} \\
2 \mathrm{MgAl}_{2} \mathrm{SiO}_{6}
\end{array}\right\}+3 \mathrm{SiO}_{2}=x \mathrm{CaMgSi}_{2} \mathrm{O}_{6}+\left(2 \mathrm{MgO}_{2} \mathrm{Al}_{2} \mathrm{O}_{3}, 5 \mathrm{SiO}_{2}\right)
$$

with the production of cordierite. But, as is well known, in contact metamorphism cordierite and diopside are mutually exclusive, and the products of this reaction under hydrostatic conditions would probably react with the production of anorthite, enstatite (hypersthene), and quartz, thus :-

$2 \mathrm{CaMgSi}_{2} \mathrm{O}_{6}+\mathrm{Mg}_{2} \mathrm{Al}_{4} \mathrm{Si}_{5} \mathrm{O}_{18}=2 \mathrm{CaAl}_{2} \mathrm{Si}_{2} \mathrm{O}_{8}+4 \mathrm{MgSiO}_{3}+\mathrm{SiO}_{2}$. Cerdierite, being a common product of thermai metamorphism, it might be expected that hypersthene would similarly arise if diopside were present in the invading magma, by assimilation of aluminous sedimentary material. In this modified sense there may be some justification for Dr. J. W. Evans' contention, mentioned by Mr. Dixey, when applied to cases where hybridism can be proved on other grounds. It is of interest to note in this connexion the example afforded by the norite intrusions of Huntly, Aberdeenshire, described by Mr. W. R. Watt (Q.J.G.S., 1914, p. 266). Monoclinic pyroxene is a normal constituent of the norite, but where the latter has been subject to contact metamorphism or has intruded sediments with transference of material, cordierite appears, but diopside is conspicuous by its absence.

C. E. Tilley. 